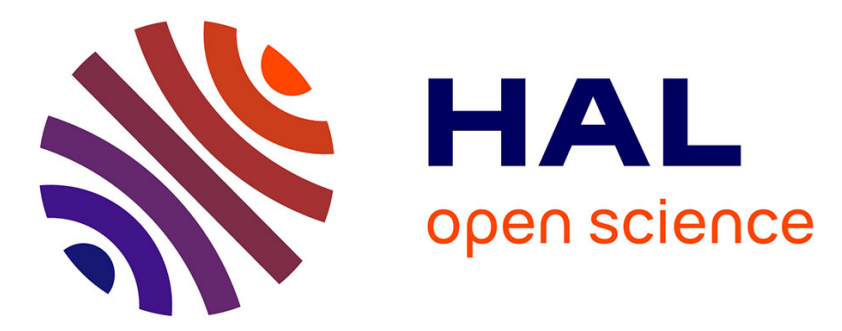

\title{
Aircraft measurements during the BEMA campaign (Burriana, Spain, June 97)
}

\author{
N. Anastasio, Alain López, Jean-Luc Attié, Pierre Durand
}

\section{To cite this version:}

N. Anastasio, Alain López, Jean-Luc Attié, Pierre Durand. Aircraft measurements during the BEMA campaign (Burriana, Spain, June 97). Physics and Chemistry of the Earth Part B Hydrology Oceans and Atmosphere, 1999, 24 (6), pp.669-672. 10.1016/S1464-1909(99)00063-5 . hal-00160458

\section{HAL Id: hal-00160458 \\ https://hal.science/hal-00160458}

Submitted on 10 Aug 2021

HAL is a multi-disciplinary open access archive for the deposit and dissemination of scientific research documents, whether they are published or not. The documents may come from teaching and research institutions in France or abroad, or from public or private research centers.
L'archive ouverte pluridisciplinaire HAL, est destinée au dépôt et à la diffusion de documents scientifiques de niveau recherche, publiés ou non, émanant des établissements d'enseignement et de recherche français ou étrangers, des laboratoires publics ou privés. 


\title{
Aircraft Measurements During the BEMA Campaign (Burriana, Spain, June 97)
}

\author{
N. Anastasio, A. Lopez, J. L. Attie and P. Durand \\ Laboratoire d'Aérologie, UMR CNRS/UPS: 5560, 14 Ave. Edouard Belin, 31400 Toulouse, France
}

\begin{abstract}
Our aim, within the framework of the BEMA programme, was to use airborne measurements as input for the initial conditions and boundary conditions for models (TVM/LCC and TVM/RACM meso-scale models) developed by ISPRA, to study the influence of biogenic emissions on the ozone formation in a Mediterranean atmospheric boundary layer. This photochemical formation is connected to a non-linear reaction kinetics involving hydrocarbon and nitrogen oxide emissions(Lopez and al.. 1989). These measurements also allowed the models to be validated.
\end{abstract}

\section{Introduction}

The changes in a chemically reactive component in the atmospheric boundary layer can be described by its budget equation. For horizontal homogeneity this can be expressed as follows:

$\frac{\partial \underline{\mathrm{C}}}{\partial \mathrm{t}}+\mathrm{u} \frac{\partial \underline{\mathrm{C}}}{\partial \mathrm{x}}=\frac{\partial \underline{\phi}}{\partial \mathbf{z}}+\mathrm{S}-\mathrm{P}$

where $\mathrm{C}$ is the mean concentration at altitude $\mathrm{z}, \phi$ the vertical flux, $S$ and $P$ the photochemical sources and sinks on the same level. The term $\partial \mathrm{C} / \partial \mathrm{t}$ represents the change in time of the concentrations, the term $\mathrm{u} \partial \mathrm{C} / \partial \mathrm{x}$ is the horizontal advection term and $\partial \phi / \partial z$ represents the divergence of the vertical flux.

Resolution of this equation requires knowledge of the initial conditions and the boundary conditions corresponding to the vertical fluxes in the surface layer and at the top of the thermal internal boundary layer. Airborne measurements allow availability to these data and provide information on atmospheric circulation through vertical profiles of mean dynamical and thermodynamical parameters.

Correspondence to: A.Lopez

\section{Presentation of the measurements}

A measurement campaign was implemented in June 1997 in the region of Castellon in Spain. The aircraft used was the French ARAT (Atmospheric and Remote Sensing Research Aircraft) belonging to IGN (National Geographical Institute) under INSU's (National Institute for the Sciences of Universe) operational responsibility. The aircraft was a FOKKER 27-MK 700 equipped to acquire mean meteorological parameters (wind, $\mathrm{T}, \mathrm{H}$, radiation), mean physical and chemical parameters (aerosols and ozone) and turbulent parameters enabling the calculation of latent, sensible, momentum and ozone fluxes.

The experimental region was a coastal plain of thirty kilometres wide where the vegetation consisted mainly of orange trees. It was characterised by an heterogeneous distribution of man-made and industrial sources of pollution that can contribute to ozone formation due to emissions of nitrogen oxides and hydrocarbons.

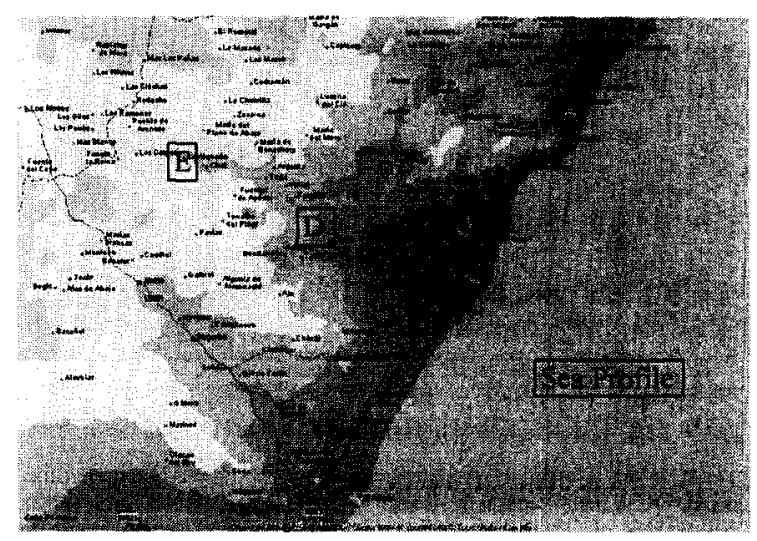

Fig.1. Experimental area

The airborne measurements were completed by a network of ground stations (points B,C,D and E, Fig.1) measuring biogenic emissions of the vegetation, the daily 
changes in $\mathrm{O}_{3}$ concentration and surface fluxes, and by measurements made from tethered balloons.

Eight aircraft flights were made during this campaign. They were of two types:

- morning flights to study vertical profiles above sea and land surfaces.

- flights in the middle of the day intended to study the change in vertical profiles in the marine Breeze Flow Layer and fluxes of matter and energy in the Surface Layer and at the top of the Thermal Internal Boundary Layer.

\section{Vertical profiles analysis}

As examples, Fig.2 shows vertical profiles for wind, potential temperature, water vapour and ozone for the afternoon of 13 June performed at sea and above the ground stations (C) and (D), between altitudes of 100 and $3000 \mathrm{~m}$.
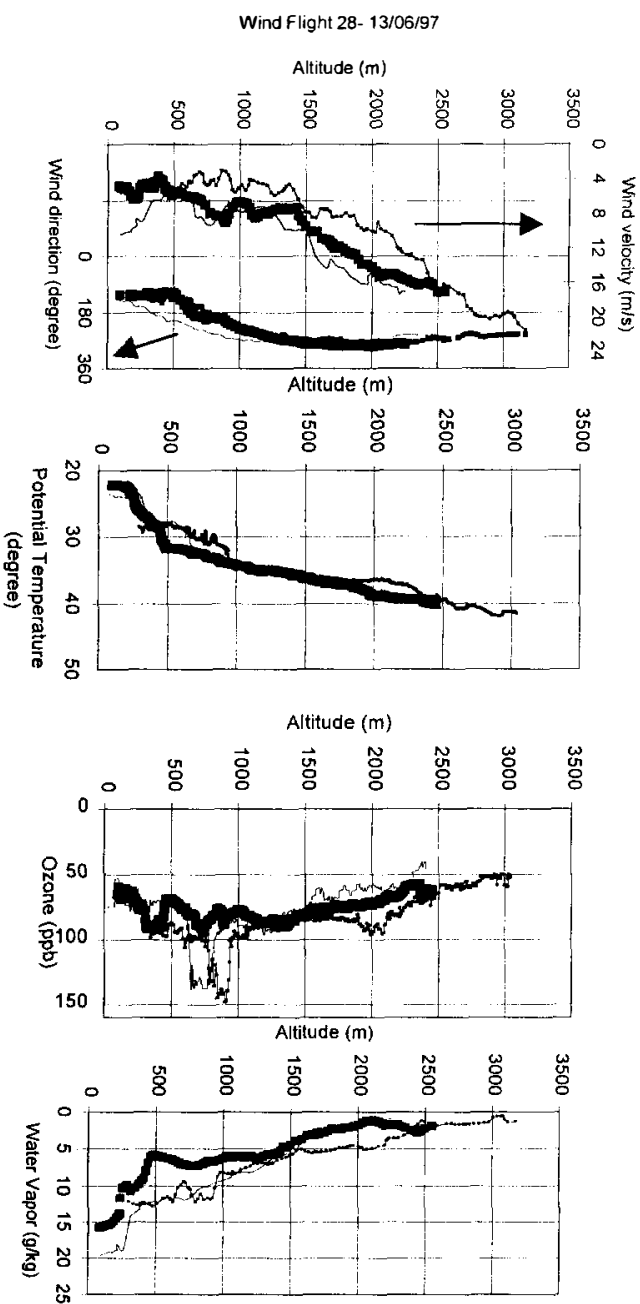

Fig.2. Wind, Potential temperature, ozone and water vapor profiles performed in the aftemoon of 13/06/97. The ( ) curves represent the sea profiles, ( $\longrightarrow$ curves profiles above site $C$ and $(\longrightarrow)$ curves profiles above site D.
We noted a rotation of the wind from the East South-East sector in the low levels to the West South-West sector higher up which characterised the current sea-breeze conditions during the day. The changes in temperature profiles enable to characterisze the development of the Thermal Internal Boundary Layer over the land in the Breeze Flow Layer. The top of this boundary layer is generally accompanied by a temperature inversion. The altitude of this inversion increased between points (C) and (D). It was $300 \mathrm{~m}$ at (C) and $800 \mathrm{~m}$ at (D). The water vapour profiles confirm this vertical structure. The ozone profiles highlight a strong concentration (of about $150 \mathrm{ppb}$ ) in the transition zone between the Breeze Flow Layer and the Return Flow Layer.

Interpolation of the measurements obtained from vertical and horizontal runs enable the representation of wind, potential temperature, specific humidity and ozone fields in a plane-perpendicular to the coast,(Fig.3,4).
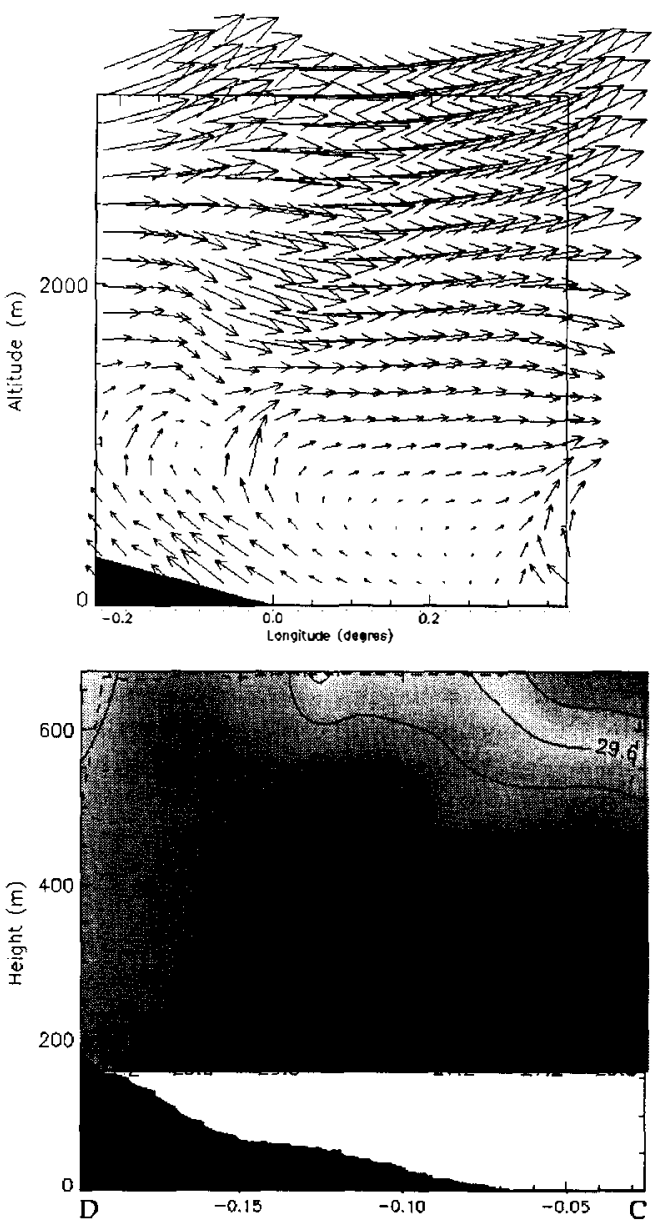

Fig.3. Wind, potential temperature (degre) fields of the aftemoon of 13/06 

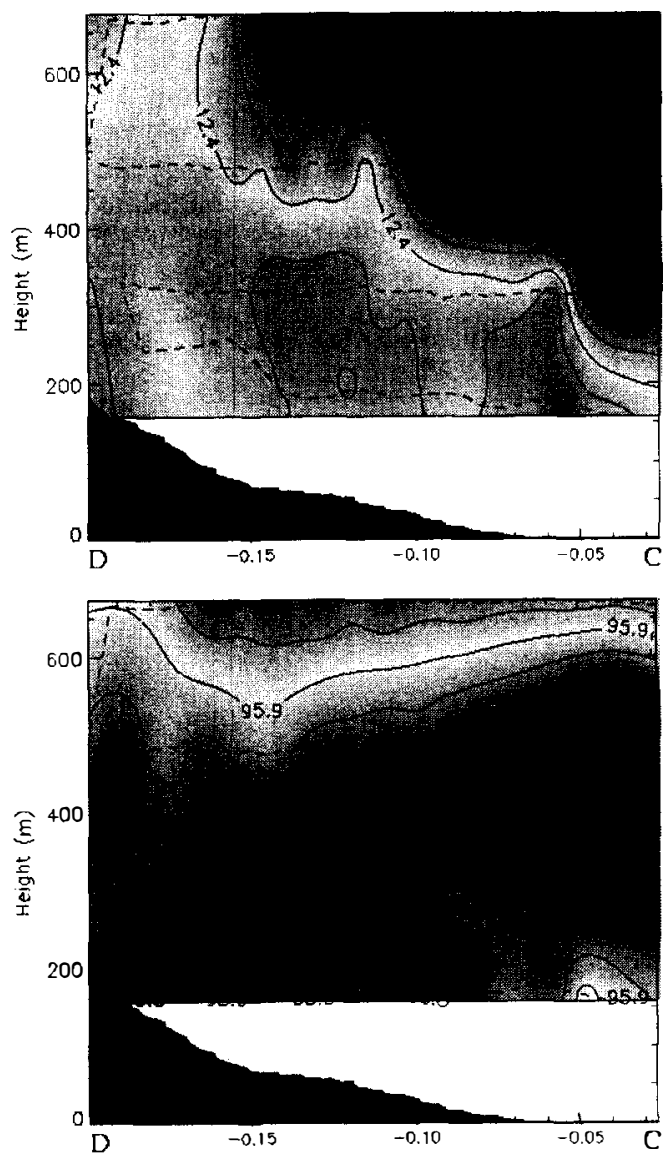

Fig.4. Specific humidity $(\mathrm{g} / \mathrm{kg})$ and ozone $(\mathrm{ppb})$ fields of the afternoon of $13 / 06$

The data were then analysed to draw up a schematic representation of the structure of the atmosphere on a plane perpendicular to the coast (Fig.5).
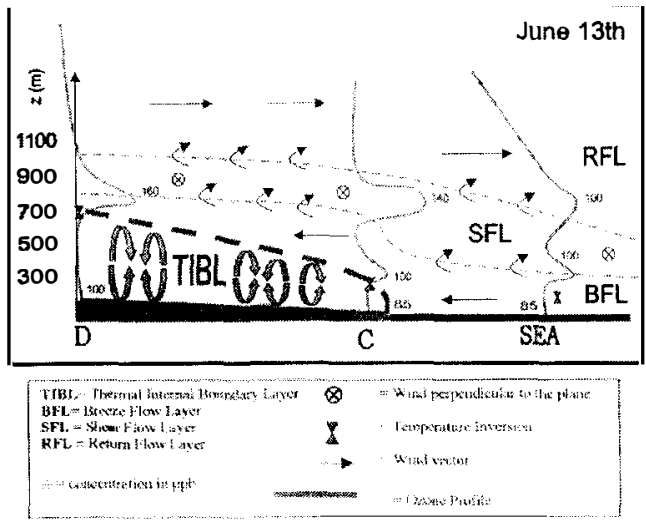

Fig.5. Schematic representation of two dimensional structure of the atmosphere (afternoon 13/06/97) (Cuvelier and al. 1998)
Four layers were defined: the Thermal Internal Boundary Layer (TIBL), the Breeze Flow Layer (BFL), the Return Flow Layer (RFL) and the Shear Flow Layer (SFL). Note that high concentrations of ozone were located in the Shear Flow Layer.

\section{Vertical fluxes measurement}

Sensible and latent heat fluxes, momentum and ozone fluxes were calculated by the eddy correlation method.

$\phi=I / T \int_{0}^{T} w^{\prime} x^{\prime} d t$

where $w^{\prime}$ represents the fluctuations of vertical wind velocity and $x$ ' the fluctuations of the different parameters. $\mathrm{T}$ represents the sample duration.

The experimental approach for turbulent flux airborne measurements was developed in a previous work (Affre et al., 1998). The experimental data were obtained on horizontal runs of about $25 \mathrm{~km}$ perpendicular and parallel to the coast. These level measurements were performed close to the ground (between $100 \mathrm{~m}$ and $200 \mathrm{~m}$ altitude according the relief ) to determine the surface fluxes and at the interface of the Thermal Internal Boundary Layer and the Breeze Flow Layer (between $300 \mathrm{~m}$ and $600 \mathrm{~m}$ ) to determine the entrainment fluxes. Fluxes were calculated by overlapping segment to represent a horizontal distance of 5 $\mathrm{km}$ (about $\mathrm{I} \mathrm{mn}$; of flight). That allows a better representation of the heterogeneous area.

Figure 6 shows the change in ozone fluxes along an axis perpendicular to the coast. At low altitude the fluxes were fairly representative of the surface fluxes. The negative values correspond to deposition on the ground and vegetation.At intermediate altitudes, the fluxes were representative of entrainment fluxes between the Internal Boundary Layer and the breeze cell. Above the Thermal Internal Boundary Layer, flux values were lower

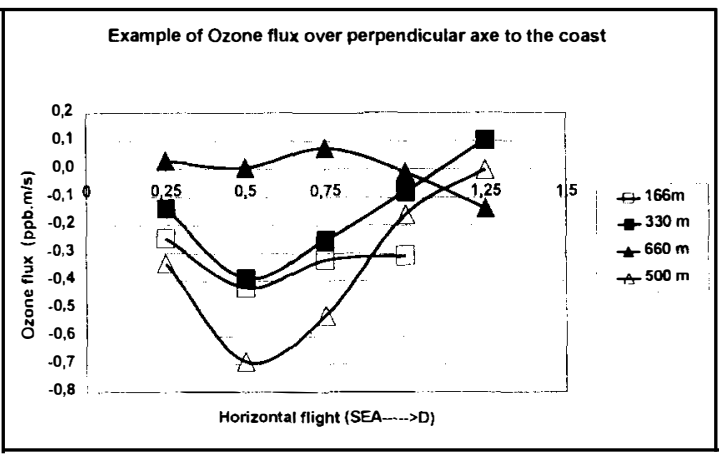

Fig.6. Evolution of ozone fluxes over horizontal runs at various altitudes. 


\section{Conclusion}

The airborne measurements enable to determine the initial and the boundary conditions needed for modelling.

Daily changes in vertical profiles were used to determine the characteristics of atmospheric circulation related to the development of a current sea breeze during the day. The measurements show strong concentrations of ozone in the Shear Flow Layer between the breeze flow and the return flow layers. The ozone fluxes were used to quantify the exchanges between the different layers. In the lower layers, these fluxes correspond mainly to deposition on the ground and vegetation. At the top of the Internal Boundary Layer, they represent entrainment fluxes with the breeze cell. The data obtained will later be compared with the results from the models.
Acknowledgments. This study was supported by the European program BEMA

\section{References}

Lopez A., Barthomeuf M.O., Huertas M.L., Simulation of the chemical processes in an atmospheric boundary layer- Influence of light and biogenic hydrocarbons on the formation of oxydants, Atmos. Environ. , vol 23, $N^{\circ} 7,1989$.

Affre C. Carrara A. Lefebre F., Druilhet A., Fontan J., Lopez A., Aircraft measurement of ozone turbulent flux in the Atmospheric Boundary Layer. Atmos. Environ. 1999.

Cuvelier C. , Thunis P. Application of the mesoscale meteorologychemistry model TVM-LCC/RACM to the study of biogenic emissions, Communication presented at EGS, Nice, 1998.. 